\title{
Forest succession in post-agricultural Larix olgensis plantations in northeast China
}

\author{
Wei $\mathrm{Ma}^{1} \cdot$ Shen $\mathrm{Lei}^{2} \cdot$ Yujun $\mathrm{Sun}^{2} \cdot \mathrm{Jason}_{\text {Grabosky }}^{3}$
}

Received: 21 August 2018/ Accepted: 26 December 2018/Published online: 11 July 2019

(C) The Author(s) 2019

\begin{abstract}
In order to understand the management of regional vegetation, numerical classification and ordination are widely used to investigate community distribution and vegetation features. In particular, two-way indicator-species analysis programs (TWINSPAN) classifies plots and species into different groups. De-trended correspondence analysis (DCA) and canonical correspondence analysis (CCA) reflects the relationship between community and site conditions. Afforestation with Larix olgensis Herry. Plantations is a suitable restoration strategy on post-agricultural fields in the Lesser Khingan Mountains. The results of this study show how these plantations develop over time to establish a reliable pathway model by measuring and clarifying the succession process. Twenty-eight
\end{abstract}

Wei Ma and Shen Lei contributed equally to this work.

Project funding: This research was supported by the Fundamental Research Funds for the Central Universities (BJFUKF201816), the Special Public Interest Research and Industry Fund of Forestry (200904003-1) and the Importation of Foreign Advanced Agricultural Science and Technology Program (2008-4-48).

The online version is available at http://www.springerlink.com

Corresponding editor: Chai Ruihai.

Yujun Sun

sunyj_1963@163.com

1 Academy of Forest Inventory and Planning, State Forestry Administration, Beijing 100714, China

2 The Key Laboratory of Silviculture and Conservation of the Ministry of Education, College of Forestry, Beijing Forestry University, Beijing 100083, China

3 New Jersey Agricultural Experiment Station, Rutgers University, New Brunswick, NJ, USA
L. olgensis plantations along a 48-year chronosequence of afforestation were investigated with a quadrat sampling method. Species composition, community structure attributes of diversity, and site conditions were analyzed. Communities were classified by TWINSPAN into five successional stages: immature, juvenile, mid-aged, nearmature and mature. Classifications were validated by DCA and CCA analysis. Site conditions such as soil and litter thickness, soil organic matter, soil density, and $\mathrm{pH}$ were measured. Successional stages varied in community composition and species population, accompanied by time from afforestation and a gradient of site conditions. This gradient showed changes in vegetation occurrence and diversity coinciding with changes in soil conditions. The study showed that L. olgensis plantations had marked predominance in growth and were associated with improved soil fertility and the formation of a stable plant community.

Keywords Chronosequence - Community structure . Lesser Khingan Mountains $\cdot$ Site conditions $\cdot$ Species composition

$\begin{array}{ll}\text { Abbreviations } & \\ \text { CCA } & \text { Canonical correspondence analysis } \\ D & \text { Margalef richness index } \\ \text { DBH } & \text { Diameter at breast height } \\ \text { DCA } & \text { De-trended correspondence analysis } \\ \text { GGP } & \text { Grain for Green Project } \\ H^{\prime} & \text { Shannon diversity index } \\ I V & \text { Importance value } \\ J & \text { Pielou evenness index } \\ \text { LLT } & \text { Thickness of litter layer } \\ \text { LOP } & \text { Larix olgensis Herry. plantations } \\ R D & \text { Relative density } \\ R D O & \text { Relative significance or coverage }\end{array}$




\section{$R F \quad$ Relative frequency \\ SOM Organic matter \\ ST Soil thickness \\ TWINSPAN Two-way indicator-species analysis programs}

\section{Introduction}

For many years, the recovery of vegetation on a site has gained increasing attention worldwide. Research has been conducted to predict the resilience and stability of new vegetation on abandoned fields (Jordan et al. 1987; Rivera et al. 2000; Chitra et al. 2009), of forest recovery after harvesting (Allen and Philip 2008), afforestation around mine sites (Bradshaw 1997; Carolina and Belén 2005), or vegetation recovery following a range of disturbances (Karel and Petr 2001; Joana et al. 2011). Equal to assessing restoration effectiveness on different land types, understanding the governing mechanisms of post-restoration seral stability or successional trajectories using anthropogenic land use changes is necessary (Connell and Slatyer 1977; Leendertse 1997; Karel and Petr 2001; Luisa et al. 2001). However, the difference between pattern and process remains unclear, as terms such as ecosystem stability and resilience are often mixed with disturbance and successional processes confusingly. Generally, successional processes are evaluated quantitatively based on community structure, species diversity, and ecosystem processes. These same parameters have been identified as essential components for the long-term maintenance of an ecosystem (Ruiz-Jaen and Aide 2005). Examining community structure provides information on vegetation patterns (Sarmiento et al. 2003; Kassi N'Dja and Guillaume 2008) and ecosystem suitability (Connell and Slatyer 1977), and helps to predict successional pathways (Coast Information Team 2004; Toledo and Salick 2006). Species diversity indices are employed to measure susceptibility to species invasion, necessary for assessing ecosystem processes (Nichols and Nichols 2003). Gradients of age and various environmental factors that contribute to vegetation development have been consistently treated as important factors affecting the long-term stability of ecosystems (Aide et al. 1996; Souza and Batista 2004). Therefore, quantifying and classifying successional stages of ecosystem recovery has become an important area of research (Lu et al. 2003; Liu et al. 2011). Many vegetation restoration projects have focused on assessing success under natural conditions (Aravena et al. 2002; Carolina and Belén 2005; Jerônimo et al. 2011), and some have been short-term studies (Elgersma 1998; Peter and Harrington 2009). Several studies have addressed the recovery of post-agricultural forests (Wang et al. 2004; Kathryn and Mark 2005; Jacquemyn and Rein 2008). In spite of their relatively small size in relation to other land uses, post-agricultural forests are considered important to reduce the fragmentation of isolated forest components (Howorth and Pendry 2006; Pieter et al. 2011).

As a source of timber, mixed broadleaf-conifer forests of the Lesser Khingan Mountains are one of the most important forests in northeast China. Large areas of this forest type have been cleared for farming but because of concerns for environmental deterioration, there are efforts to reclaim these agricultural lands for forest development. Faced with these efforts over large parts of China (Li et al. 2008), the Grain for Green Project (GGP) was developed to become an influential environmental project attracting international attention. According to the GGP, these forests need to return to a stable and sustainable ecosystem through ecological restoration. Plantations of Larix olgensis represent an important recovery for previously farmed lands. As an artificial community, these plantations are homogeneous in age and structure. Over time, the interaction between the community and site conditions influences the differentiation in community characteristics. However, the development and long-term maintenance of plantations are under study in the Lesser Khingan Mountains.

This paper evaluates the establishment of $L$. olgensis on previously cultivated agricultural fields. The objectives of this study were to measure and clarify the successional process to establish a pathway model for vegetation restoration. Specifically, several metrics of community structure, composition and site properties were compared to analyze the changes in ecological relationships and species diversity during succession. The goal was to describe the mechanism of succession of Larix olgensis and to propose a strategy for ecological restoration on farmlands in the Lesser Khingan Mountains.

\section{Materials and methods}

\section{Study site}

The study was carried out on Dongzhelenghe Forest Farm $\left(\mathrm{N} 46^{\circ} 31^{\prime}-46^{\circ} 49^{\prime} ; \mathrm{E} 128^{\circ} 5^{\prime}-129^{\circ} 15^{\prime}\right)$, a typical region in the Lesser Khingan Mountains which has a continental monsoon climate, characterized by average annual precipitation of $618 \mathrm{~mm}, 0.36{ }^{\circ} \mathrm{C}$ mean annual temperature, average relative humidity of $68 \%$, and average annual frost-free period of 100 days. The dominant landform is high forest covered hills with an elevation varying from 200 to $600 \mathrm{~m}$ a.s.l., and average slope about $7^{\circ}$. The primary soil type is 
dark-brown forest soil with little gravel, and thickness of $30-60 \mathrm{~cm}$. The peak growing season starts in early July and ends in late August in this region.

Forests are classified as temperate mixed broadleafconifer forests based on the system of Chinese national vegetation regionalization (Cao and $\mathrm{Li}$ 2007). While land was cleared for agriculture, some sites have reverted back to forests. For example, abandoned corn and soybean fields which were surrounded by forest, have been gradually reverted to forest since the mid-1960s for planting with $L$. olgensis. This study focuses on plantations that have returned farmlands that were previously forested back to a forest cover. The oldest plantation in our study had been established in 1962, while the youngest was established in 2002 when the Grain for Green Project was officially started. The vertical structure of $L$. olgensis plantations can be divided into canopy, shrub, and herb layers. L. olgensis accounted for more than $60 \%$ of the canopy volume, as the most dominant species. Associated species were Ulmus pumila L., Acer mono Maxim., Picea jezoensis var. komarovii (V.N. Vassil.) W.C. Cheng and L.K. Fu with other species occurring occasionally. Shrub species were mainly Philadelphus schrenkii, Sorbaria sorbifolia, Lonicera chrysantha, Acanthopanax senticosus, and Deutzia parviflora. Herbs were Cardamine leucantha, Filipendula palmata, Carex callitrichos, Pteridium aquilinum, and Impatiens nolitangere.

\section{Sampling}

To study the successional processes of L. olgensis plantations on farmlands, samples were collected simultaneously at different successional stages using a space-for-time substitution (Carolina and Belén 2005). In 2010, twentyeight random plantations with initial planting densities of 2883 seedlings per hectare were selected to represent a 48-year chronosequence. They were distributed among five age classes: $7-10$ years $(\mathrm{n}=4) ; 11-19$ years $(\mathrm{n}=6)$; 21-27 years $(\mathrm{n}=10) ; 32-37$ years $(\mathrm{n}=5) ; 41-48$ years $(\mathrm{n}=3)$. The plantation age of these former farmlands were obtained from inventory data of the Dongzhelenghe Forest Farm; all plantations were under similar management. Quadrat plots $20 \mathrm{~m} \times 30 \mathrm{~m}, 5 \mathrm{~m} \times 5 \mathrm{~m}$ and $1 \mathrm{~m} \times 1 \mathrm{~m}$ were used for tree, shrub and herb inventories, respectively. Five shrub quadrats were set at the center and corners of the $20 \mathrm{~m} \times 30 \mathrm{~m}$ plot, and twenty herb quadrats were at the corners of each shrub quadrat. Soil profiles in the center of the plot and four evenly distributed points on diagonals were established for collecting soil samples.

\section{Evaluation}

In each quadrat, the number and average height of all plant species were tallied and the diameter at breast height (DBH, $1.3 \mathrm{~m}$ ) of each canopy species were measured. The percent cover of shrub and herb species was determined. The survey was restricted to woody species with a DBH > $5 \mathrm{~cm}$, which is consistent with a previous study with a similar length of chronosequence by Howorth and Pendry (2006). The total number of species was 112 , including 18 , 21 and 73 for tree, shrub, and herbs, respectively. Thirtyfive dominant species were recorded (Table 1). Site factors of elevation, slope, litter layer thickness, and soil thickness were measured by GARMIN eTrex $\mathrm{H}$ handheld GPS, compass, and steal tape. Numeric ranks were used to express the position of slope and aspect for establishing site condition matrix. Upper, middle and lower slope positions were designated by 1,2 and 3, respectively. Aspect was divided into eight groups of $45^{\circ}$ sections. Given the predominant aspect in the field, $247.5^{\circ}-292.5^{\circ}$ became aspect 1 , with aspect 2 corresponding to $292.5^{\circ}-337.5^{\circ}$. Soil samples were collected from four points in each plot, blending into a single batch sample for testing physical and chemical characteristics. Soil $\mathrm{pH}$ was measured by potentiometric technique (McKeague 1978), and soil organic matter by heating outside the potassium dichromate volumetric technique (Man et al. 2010).

\section{Data analysis}

After floristic inventories in 28 plots, 112 species importance values were calculated by relative density, frequency, and significance (tree) or coverage (shrub, herb) using the following formula:

$I V=(R D+R F+R D O) / 3$

where $I V$ is the importance value, $R D$ the relative density, $R F$ relative frequency, and $R D O$ relative significance or coverage.

An $I V$ matrix of 122 species $\times 28$ plots and a site condition factor matrix of 28 plots $\times 9$ site factors were developed and standardized by logarithmic conversion as a basis of the succession analysis.

A two-way indicator-species analysis (TWINSPAN) in WinTWINS software packages (Hill 2005) was used to classify the successional stages of the communities with the $I V$ matrix.

The number of species was analyzed by ANOVA followed by a Tukey post hoc analysis for multiple comparisons (SPSS 16.0). The Sorensen similarity index was used to analyze species composition of communities at different stages in terms of species number in each layer or community based on the following formula: 
Table 1 Importance values of main species in five succession communities

\begin{tabular}{|c|c|c|c|c|c|c|}
\hline Layers & Species & I & II & III & IV & $\mathrm{V}$ \\
\hline \multirow[t]{7}{*}{ Tree } & Larix olgensis Herry. & 83.06 & 71.37 & 68.31 & 59.53 & 57.65 \\
\hline & Quercus mongolica Fisch.ex Turcz. & 5.84 & & & & \\
\hline & Acer mono Maxim. & 5.63 & 4.83 & 9.71 & & \\
\hline & Fraxinus mandshurica Rupr. & & 5.24 & & & \\
\hline & Ulmus pumila L. & & 10.69 & 6.06 & 9.46 & 14.08 \\
\hline & Betula platyphylla Suk. & & & 5.37 & 12.91 & 5.02 \\
\hline & Picea jezoensis var. komarovii & & & & & 7.80 \\
\hline \multirow[t]{7}{*}{ Shrub } & Spiraea salicifolia $\mathrm{L}$. & 53.81 & & & & \\
\hline & Rosa multiflora Thunb & 16.19 & & & & \\
\hline & Lonicera chrysantha Turcz & 30.00 & 18.29 & & & \\
\hline & Viburmum sargentii Koehne & & 31.43 & 27.30 & & \\
\hline & Corylus mandshurica Maxim & & 11.52 & 15.87 & 11.75 & 22.94 \\
\hline & Sorbaria kirilowii (Reqel) Maxim & & & 16.83 & 18.61 & 15.90 \\
\hline & Philadelphus schrenkii Rupr. & & & & 14.44 & 17.28 \\
\hline \multirow[t]{8}{*}{ Herb } & Artemisia stolonifera (Maxim.) Komar. & 17.93 & & & & \\
\hline & Dryopteris crassirhizoma Nakai. & 4.98 & 6.06 & & & 9.31 \\
\hline & Filipendula palmata (Pall.) Maxim. & 10.18 & 6.49 & 8.96 & 8.12 & \\
\hline & Cardamine leucantha (Tausch) O. E. Schulz & 3.38 & 18.52 & 6.42 & 12.11 & \\
\hline & Carex lanceolata Boott & 28.92 & 15.21 & 32.02 & 14.71 & 19.42 \\
\hline & Impatiens nolitangere $\mathrm{L}$. & & 10.58 & 6.80 & 15.90 & 12.32 \\
\hline & Sium suave Walt & & & 9.99 & 9.19 & 9.44 \\
\hline & Oxalis corniculata $\mathrm{L}$. & & & & & 15.91 \\
\hline
\end{tabular}

$C C=2 a /(b+c)$

where $C C$ is the Sorensen similarity index, $a$ the number of the same species in two communities being compared, $b$ and $c$ the numbers of species in each of the communities in the comparison.

De-trended correspondence analysis (DCA) and canonical correspondence analysis (CCA) in CANOCO (Pinder et al. 1997; Ter Braak and Šmilauer 2002; Lep and Milauer 2003) were used to analyze the relationships between the succession stages using the $I V$ and site condition factor matrices. By way of DCA and CCA, graphic ordination maps of plots (or plot groups defined by TWINSPAN), were developed to show the distribution patterns as well as the relationships among them.

After the quantitative analysis of vegetation, three diversity indices (including heterogeneity, evenness and richness) of the species in each plot were measured to reveal their variation along the stand age gradient. General equations were adopted to calculate the Shannon heterogeneity index (Pielou 1975), the Pielou evenness index (Whittaker 1972) and the Margalef richness index (Clifford and Stephenson 1975).

\section{Results and analysis}

\section{Classification of succession stages}

The twenty-eight plots were classified into groups of three and five on different levels using TWINSPAN (Fig. 1). Based on the measurements and field observations, the dendrogram defined five different successional stages of

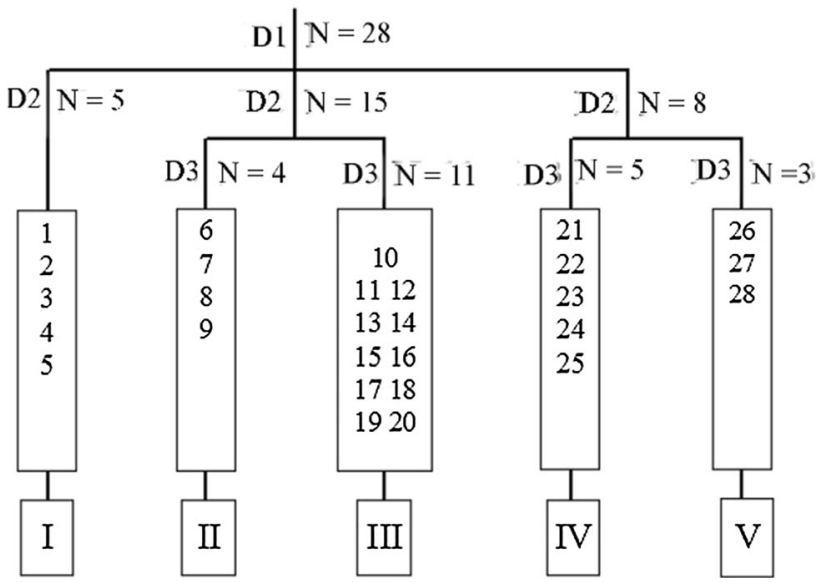

Fig. 1 Dendrogram of 28 plots by TWINSPAN, $D i$ refers to the $i$-th level of classification, $N$ shows the number of plots in a group, Arabic and Roman numerals represents plot identifiers and different succession stages, respectively 
communities when adopting the D3 level result. Each successional stage included several different communities over the time since afforestation and the changes of dominant species. In general, these plantations belong to five successional stages: immature (I), juvenile (II), mid-aged (III), near-mature (IV) and mature (V). Also, based on the community composition and structure, the five successional communities were named as combinations of dominant and indicator species to each layer. A succession model of restoration from farmland to forest land can be estimated based on them. More details about species composition, structural characteristics of communities and site conditions at different succession stages are described below.

\section{Immature (I): Larix olgensis-Carex lanceolata}

This regeneration stage was developed from farmland and started the year following afforestation. This association included plots 1-5 which occurred on middle or lower southwest gentle slopes between 299 and $354 \mathrm{~m}$ 7-11 years after planting. Due to the open environment and without fertilization, organic matter (soil thickness $40.7 \mathrm{~cm}$ ) dropped from $17.7 \mathrm{~g} \mathrm{~kg}^{-1}$ of arable fields to $16.1 \mathrm{~g} \mathrm{~kg}^{-1}$, with little surface organic litter. It was the primary period of the restoration progress and took 11 years to reach the juvenile stage. After planting $L$. olgensis, herbs quickly emerged in great numbers during this stage. The total coverage of the community was around $90.4 \%$. The coverage of tree, shrub and herb layers was 18.6, 2.3 and $86.5 \%$, respectively. L. olgensis had an advantage in the canopy layer, whose importance value ratio reached $83.06 \%$. Trees were $3.0-8.1 \mathrm{~cm} \mathrm{DBH}$ and 3.1-7.3 m height. Population densities were 1963-2184 trees $\mathrm{ha}^{-1}$. Herb layer species were abundant, $23.5-36.7 \mathrm{~cm}$ in height, and exhibited a high level of ground coverage. Only a few invasive trees and shrubs were to be found.

\section{Juvenile (II): Larix olgensis-Viburmum sargentii- Cardamine leucantha}

The juvenile stage usually started 11 years after the establishment of Larix, and the previous farmland had formed a relatively stable forestland. Plots as 6-9 were in this association and were in the middle or lower gentle hills with aspects between southeast and southwest, at an elevation of around $300 \mathrm{~m}$. The close environment enabled the conversion of gradually accumulated litter into organic matter and then into the soil. Soil development during this restoration stage brought better conditions than the immature stage. For example, soil thickness (ST) was $44.3 \mathrm{~cm}$ and organic matter (SOM) $17.0 \mathrm{~g} \mathrm{~kg}^{-1}$. The total coverage of the community was $70.4 \%$, attributed to the rapid growth of vegetation under management that included pruning, tending and thinning. The tree layer was 56.4-62.7\%, meaning the canopy had closed. L. olgensis remained the dominant species with 10.0-12.7 $\mathrm{cm} \mathrm{DBH,}$ 9.3-15.8 m heights, and population densities of 1560-1623 trees ha. Some companion species appeared such as $V$. sargentii and Lonicera chrysantha. Shrubs were invading at heights of $1.2-1.4 \mathrm{~m}$ and coverage of $16.4-23.4 \%$ that required managing; the most common species were $C$. leucantha, L. chrysantha, and Corylus mandshurica. Due to the significant canopy cover, the herb layer decreased sharply to $21.4-31.4 \%$. The main herb species included $C$. leucantha, Carex lanceolata and Impatiens nolitangere.

\section{Mid-aged (III): Larix olgensis-Viburmum sargentii-Carex lanceolata}

This stage developed from the juvenile stage 19-30 years after the change in land use. This association was consisted of plots 10-20 that occupied the lower position of southeast hills between 304 and $354 \mathrm{~m}$ at $5^{\circ}-10^{\circ}$ gradient. The litter layer thickness was up to $3.3 \mathrm{~cm}$ which contributed to the upper layer of soil that was $46.8 \mathrm{~cm}$ deep. The SOM $19.7 \mathrm{~g} \mathrm{~kg}^{-1}$ of the forest at this stage of succession exceeded that of the farmland. The coverage of the tree, shrub and herb layers was $83.4 \%, 25.3 \%$, and $19.7 \%$, respectively. L. olgensis was the dominant species of the canopy, with a mean DBH of $15.2-15.8 \mathrm{~cm}$, heights of 15.8-16.0 m, and densities of 1114-1352 trees ha ${ }^{-1}$. The main companion species were Acer mono and Betula platyphylla. The shrub layer developed quickly, with the dominant species of $V$. sargentii and main companion species were Sorbaria kirilowii and C. mandshurica. Although the herb species richness decreased, the herb layer was gradually recovering from then, with the dominant species being $C$. lanceolata and main companion species Sium suave and Filipendula palmate.

\section{Near-mature (IV): Larix olgensis-Sorbaria kirilowii- Impatiens nolitangere}

The near-mature stage developed from the mid-aged stage through a second thinning and usually started after 30 years. This association included plots $21-25$ on the middle position of southeast to southwest hills at approximate $380 \mathrm{~m}$ with a $6^{\circ}$ gradient. On the forest floor, the litter layer (LLT) was $4.3 \mathrm{~cm}$ and the soil $48.1 \mathrm{~cm}$. The SOM was $21.3 \mathrm{~g} \mathrm{~kg}^{-1}$ and considered an improvement in soil quality. The total coverage of this near-mature community was around $83.4 \%$. The tree coverage was $72.1 \%$, which was less than that of the mid-aged community due to thinning. Also because of the thinning, shrub and herb 
layers continued to grow steadily with coverage of 26.4 and $30.2 \%$, respectively. L. olgensis remained the dominant species of the tree layer, with average DBH of $16.1-16.6 \mathrm{~cm}, \quad 16.3-17.2 \mathrm{~m}$ heights, and 783-936 trees $\mathrm{ha}^{-1}$. The dominant species of the understory were $S$. kirilowii and I. nolitangere. The species diversities of the association increased rapidly. The main companion species in this community were $B$. platyphylla, U. pumila, Philadelphus schrenkii, C. mandshurica, C. lanceolata and C. leucantha.

\section{Mature (V): Larix olgensis-Philadelphus schrenkii-Carex lanceolata}

The mature community was developed from the near-mature community starting 40 years after the farmland was afforested. It was the most advanced succession stage in the study area. Plots 26,27 and 28 belonged to this association and were located on the lower $10^{\circ}$ slopes with southeast aspects at $310 \mathrm{~m}$ elevation. The litter layer reached a maximum $4.6 \mathrm{~cm}$ for the long time accumulation. Similarly, the highest value of soil thickness was $52.3 \mathrm{~cm}$ and soil organic matter was $19.7 \mathrm{~g} \mathrm{~kg}^{-1}$ were also found in this stage. The canopy coverage had fallen to $60.3 \%$, but shrub and herb covers increased to 36.8 and $50.4 \%$, respectively. The total coverage of the community was over $90 \%$. $L$. olgensis, $P$. schrenkii, and C. lanceolata were the dominant species of the tree, shrub and herb layers, respectively. The importance value of $L$. olgensis was lower than in the preceding stages, but the importance value contribution ratio of these three dominant species was as high as $31.3 \%$. The most common species included $U$. pumila, S. kirilowii, and Oxalis corniculata. The mean DBH of L. olgensis was $27.4-29.2 \mathrm{~cm}$, with heights of $26.3-28.4 \mathrm{~m}$, and 520-576 trees $\mathrm{ha}^{-1}$.

\section{Ordination analysis of succession}

\section{DCA ordination diagram of plots}

DCA ordination eigenvalues $(\lambda)$ of the top two axes were 0.893 and 0.757 , and the joint explained variation was 61.1\%. The AX1 and AX2 were used to draw two-dimensional scatter diagrams (Fig. 2) of the plots. AX1-DCA represented a successional gradient of time since afforestation and a soil thickness gradient, as the succession periods became longer and soil becomes thicker from right to left. Correspondingly, the types of community varied recognizably from right to left. AX2-DCA represented the gradient of leaf litter thickness and soil organic matter (Fig. 2). The succession community types, classified by TWINSPAN, show a trend from immature to mid-aged to mature. Immature communities (I) located in the lower

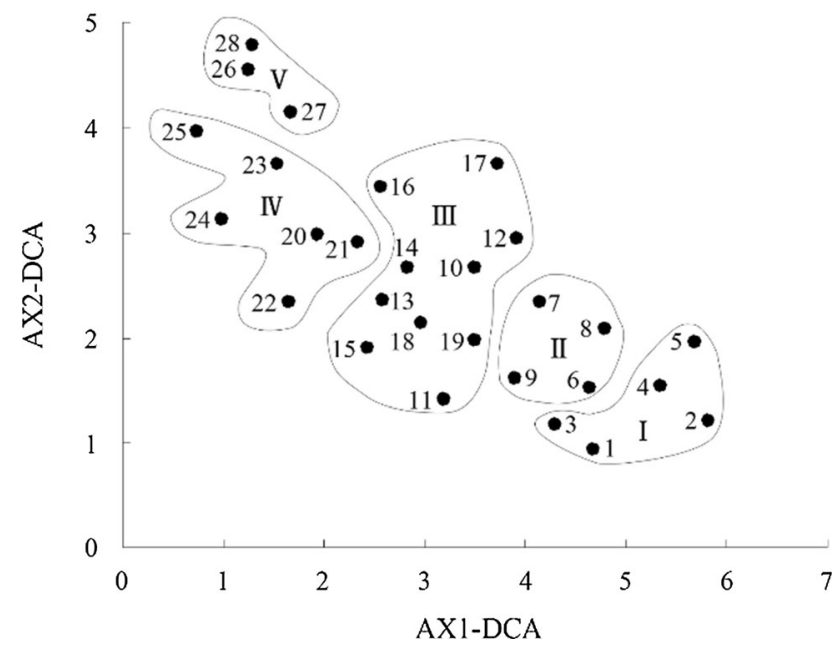

Fig. 2 Two dimensional ordination diagram of 28 plots by DCA. Arabic numerals represent 28 plots and Roman numerals represent five succession stages

right corner, mid-aged communities (III) in the center and mature communities $(\mathrm{V})$ in the top right of the scatter diagram. Community types aggregated in their own distribution range with clear boundaries. In other words, the two-dimensional scatter diagram accurately reflects the relationship among communities as well as the relationship between communities and site conditions. $I V \mathrm{~s}$ of $L$. olgensis declined from $83.1 \%$ in stage I to $68.3 \%$ in stage III to $57.7 \%$ in stage V (Table 1). Moreover, the species diversities of the community gradually increased. As such, the direction of succession and its process were represented in the DCA ordination process and analysis for this study.

\section{CCA ordination of plots}

According to the classification of the 28 plots, further analysis of the five succession communities was developed by CCA ordination. In Fig. 3, each site condition is indicated by an arrow, the length of which illustrates the correlation between community distribution and site condition. The quadrant in which the arrow is located distinguishes a positive or negative correlation. The CCA axes, especially the first and second axes, were strongly linked to site conditions, with ordination eigenvalues $(\lambda)$ of 0.426 and 0.337 . The correlations of species-site condition were $82.1 \%$ and $75.1 \%$, and the percentage accumulation of species-site condition variation was $54.1 \%$.

The first CCA axis (AX1-CCA) has a significant positive correlation with LLT, and also with ST and SOM (Fig. 4; Table 2). In other words, LLT became thicker from left to right along AX1-CCA. The same changes were with ST and SOM as well. AX1-CCA reflected the changes of slope aspect from east to west, and rising position on the slope from left to right in the ordination plot. The second 


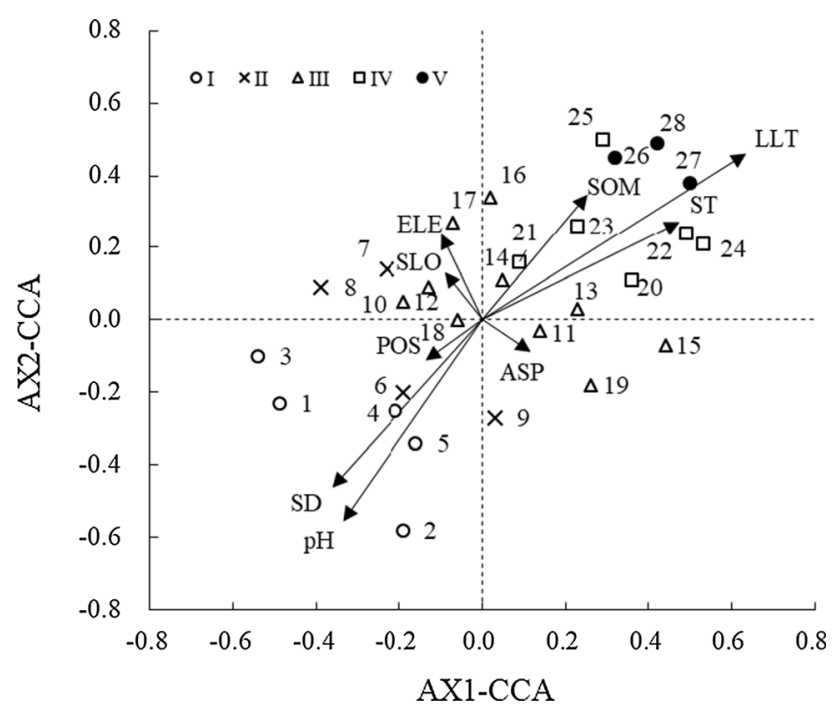

Fig. 3 Two dimensional CCA ordination diagram of 28 plots. $L L T$ litter layer thickness, $S T$ soil thickness, $S O M$ soil organic matter, $p H$ soil $\mathrm{pH}, S D$ soil density, ELE elevation, $A S P$ aspect, $S L O$ slope, $P O S$ slope position

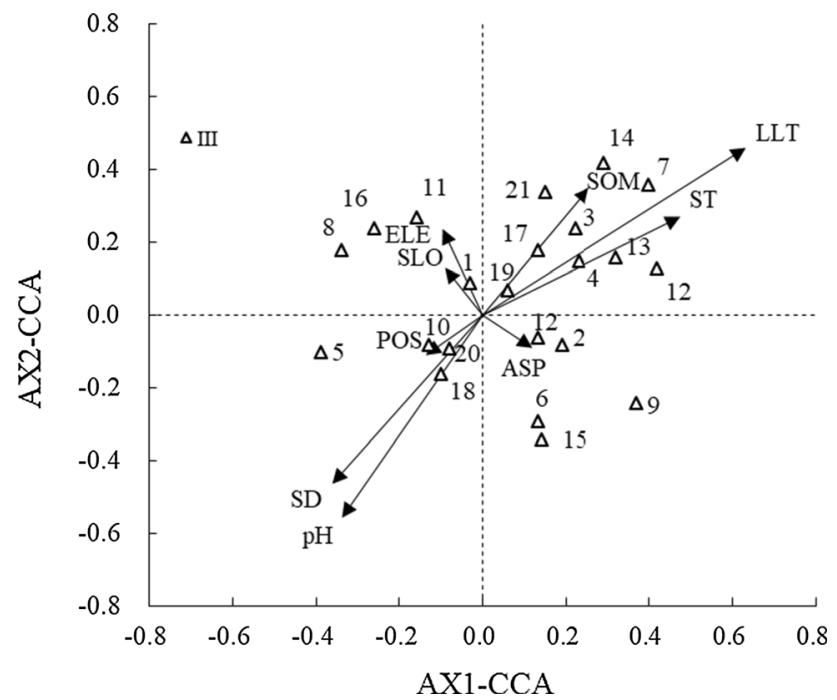

Fig. 4 Two dimensional CCA ordination diagram of main species. (1 Larix olgensis; 2 Acer mono; 3 Ulmus pumila; 4 Betula platyphylla; 5 Quercus mongolica Fisch.ex Turcz.; 6 Fraxinus mandshurica; 7 Picea jezoensis var. komarovii; 8 Spiraea salicifolia; 9 Rosa multiflora; 10 Lonicera Chrysantha; 11 Viburmum sargentii; 12 Corylus mandshurica; 13 Sorbaria kirilowii; 14 Philadelphus schrenkii; 15 Artemisia stolonifera; 16 Dryopteris crassirhizoma; 17 Filipendula palmata; 18 Cardamine leucantha; 19 Carex lanceolata; 20 Impatiens nolitangere; 21 Sium suave; 22 Oxalis corniculata)

CCA axis (AX2-CCA) is significantly negatively related to $\mathrm{pH}$ and SD but is positively associated with elevation and slope. As the values increased on the AX2-CCA axis, the litter layer became thicker and eventually transformed into more SOM, which lowered the SD and the $\mathrm{pH}$. Changes in elevation, slope, position and aspect were not as notable over their limited range. Thus, $L$. olgensis played a crucial role in community development.

The distribution of plots on CCA ordination diagram shows the relationship between successional communities and site conditions. Immature communities are located in the lower left corner, associated with higher $\mathrm{pH}$ and SD. The juvenile and mid-aged community are in the center. Near-mature and mature communities are in the upper right quadrant with deeper LLT, deeper ST and more SOM.

\section{CCA ordination of main species}

The distribution of the main species within different communities was also influenced by site conditions, following the same trends as the CCA plot ordination (Fig. 5). Since the site conditions showed significant changes from one succession stage to the next, it therefore follows that the composition of associated dominant species differed. $L$. olgensis and $C$. lanceolata were dominant in all communities (Table 1), and were located in the core of the CCA ordination plot. Some adaptable species such as $C$. mandshurica, C. leucantha and I. nolitangere appeared at several successional stages. These species had relatively unlimited space for development and were also located near to the centre of the CCA ordination plot. However, other species that were not found in all succession stages showed two main distribution cases. In one case, species were present only at one community stage as absolute or secondary dominant species throughout the distribution area of the community, e.g., Quercus mongolica (immature stage). The other distribution case was characterized as limited species occurrence in transition or at borders between specific succession communities. For example, B. platyphylla located on the upper-right corner of the ordination plot as it appeared in near-mature and mature communities.

\section{Changes in community structure}

There were significant differences in the number of species among successional communities (Fig. 6). At the beginning, the immature community had 49 species, most were herbs. Herb numbers continued to decrease until the midaged community, beyond which point the differences among successional communities were not significant at $p>0.05$. Conversely, the number of shrub species reached a maximum in the mid-aged community after about 20 years of rapid development $(p<0.05)$, and then declined slightly $(p>0.05)$. Dynamic changes in the number of tree species were similar to that of the shrub layer; they increased slowly and peaked during the nearmature stage but dropped drastically in the mature community. L. olgensis numbers declined from the initial high planting density. After 40 years of site restoration, there 
Table 2 Correlation coefficients between site condition variables and CCA ordination axes across 28 LOP plots

\begin{tabular}{|c|c|c|c|c|}
\hline \multirow[t]{2}{*}{ Site condition variables } & \multicolumn{4}{|c|}{ CCA Ordination axis } \\
\hline & Axis 1 & Axis2 & Axis3 & Axis4 \\
\hline Litter layer thickness & $0.7835^{* * *}$ & $0.52403 * *$ & 0.1293 & 0.1746 \\
\hline Soil thickness & $0.3322 * * *$ & $0.4964 * * *$ & $-0.2679 * *$ & -0.0574 \\
\hline Soil pH & $-0.3463 * *$ & $-0.6515^{* * *}$ & $0.38103 * *$ & 0.19563 \\
\hline Soil density & $-0.3573^{* *}$ & $-0.4867 * * *$ & 0.2096 & $0.6142 * * *$ \\
\hline Soil organic matter & $0.6473 * * *$ & $0.3190 * *$ & $-0.4337 * * *$ & $0.2901 *$ \\
\hline Elevation & 0.0852 & $-0.2573 * *$ & $-0.3153 * *$ & 0.1650 \\
\hline Slope & $0.15983^{*}$ & $-0.2617 * *$ & $-0.2820 * * *$ & 0.1055 \\
\hline Aspect & $-0.2629 * *$ & 0.1103 & $-0.3138 * * *$ & 0.0961 \\
\hline Slope position & -0.0611 & -0.0492 & 0.1478 & $0.2293 * *$ \\
\hline
\end{tabular}

At the same time, comparisons of Sorensen indices

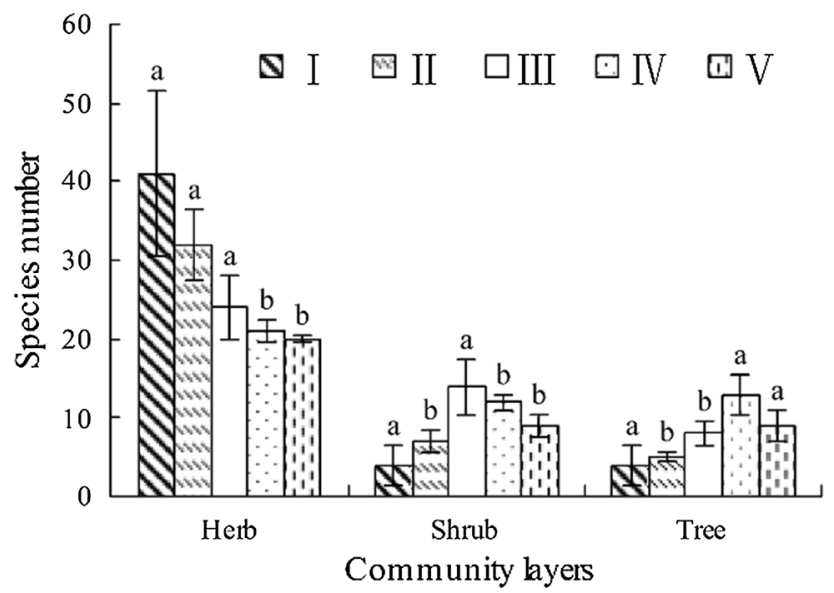

Fig. 5 Changes in species numbers of community layers at different stages (mean $\pm \mathrm{SD}$ ). Superscript letters indicate significant difference at 0.05 level

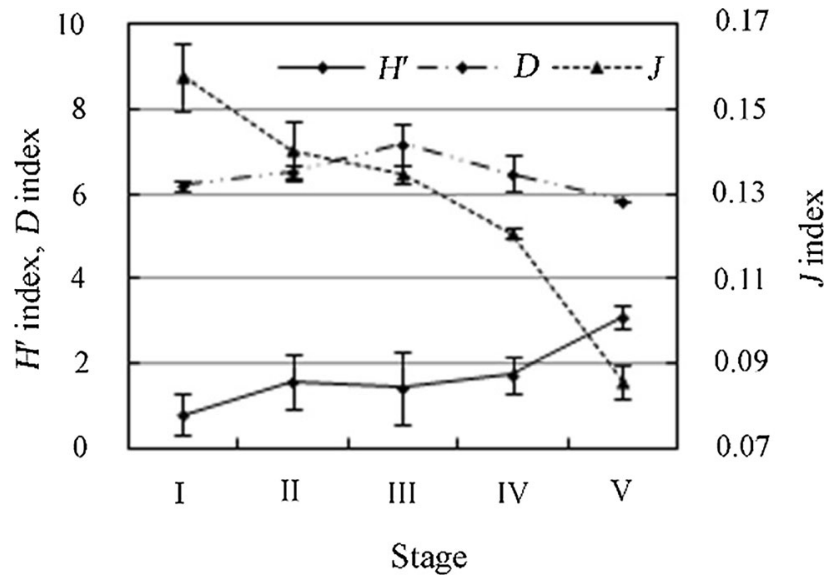

Fig. 6 Changes of diversity indices of community at different stages (mean $\pm \mathrm{SD}$ )

were significant variations $(p<0.05)$ between mature and immature communities within herb, shrub and tree layers. among the five stages indicate that species composition varied with the stages (Table 3). Sorensen indices of the canopy, understory vegetation and herb communities decreased as the intervals of successional stages increased. The results show that understory vegetation and at the whole community level, there were definite changes as successional stages increased, while the canopy was more stable within the confines of the Sorenson index. Importance values of main species in different successional communities were distinct (Table 1). IVs of species can predict changes in species domination over time. Differences in species composition also reflect the natural colonization process and the results of competition for resources. In the canopy layer, $I V \mathrm{~s}$ of $L$. olgensis decreased from 83.06 to 57.65 due to the relatively difficult natural regeneration of the species. However, population numbers of other associated species were increasing as they gradually entered the canopy. In the shrub layer, some dominant species were replaced small shrubs and formed stable shrub populations such as $C$. mandshurica. In the herb layer, some light-demanding herbs quickly established as pioneers like Artemisia stolonifera but did not persist over time. In contrast, Carex spp. populations covered the ground rapidly at the beginning of site conversion and remained one of the most dominant species during the succession process. I. nolitangere and other semi-humid herbs developed into dominant species over multiple successional stages. In fact, pioneer species of $U$. pumila, $C$. mandshurica, and Carex spp. were successful colonizers and played important roles in vegetation restoration of farmlands. Generally the understory vegetation, (especially herbs), was changing along with the dynamic variation of the canopy density, which directly affected light, soil water and other site conditions (Stephane and Dawn 2001). 
Table 3 Coefficient of community similarity among different stage communities

\begin{tabular}{lllllllllll}
\hline Layers & I-II & I-III & I-IV & I-V & II-III & II-IV & II-V & III-IV & III-V & IV-V \\
\hline Arbor & 0.667 & 0.500 & 0.353 & 0.273 & 0.615 & 0.444 & 0.429 & 0.571 & 0.588 & 0.636 \\
Shrub & 0.364 & 0.222 & 0.250 & 0.000 & 0.571 & 0.421 & 0.375 & 0.692 & 0.609 & 0.571 \\
Herb & 0.400 & 0.400 & 0.387 & 0.341 & 0.517 & 0.473 & 0.407 & 0.578 & 0.545 & 0.634 \\
Community & 0.421 & 0.379 & 0.358 & 0.230 & 0.543 & 0.457 & 0.405 & 0.609 & 0.571 & 0.619 \\
\hline
\end{tabular}

a lower evenness, as species dominance skewed the occurrence of the species within the community.

Analysis and interpretation of the three indices provide an assessment of the ground observations and their logical progression. As generalized averages, the values of $H^{\prime}, D$, and $J$ of Larix olgensis in this area were 1.733, 6.444 and 0.128 respectively. structural characteristics and the distinctions of systematic levels. Shannon diversity index $\left(H^{\prime}\right)$, Pielou evenness index $(J)$ and Margalef richness index $(D)$ present different patterns of change tendency with increasing stand age (Fig. 6).

$H^{\prime}$ increased during the community successional process as might be expected when transforming farmland to a single species plantation. While herbs comprised the bulk of species, and thus diversity components in the early stages, the development of a Larix canopy and the natural development of shrub and other tree species as components increased species occurrence and weighed diversity measures at a greater level than losses in the herb component. The situation began to change during the mature stage as the $H^{\prime}$ increase due to Larix was in decline as other competing species gradually assumed codominance in the canopy.

In the immature stage of succession, many herbaceous species occurred because of the open environment of full sunlight, but large tracts of herbs seldom occurred after the initial stage of establishment. Species richness increased with the development of populations of some species, the addition and development of others in the shrub and tree layers and the significant decrease in herb species during the successional process. When some species were able to coexist, the total number became relatively stable.

With the growing numbers of broadleaf species, shrubs and herbs, the $J$ distribution decreased during the successional stages and the number of dominant species increased, leveling the evenness in distribution. These species roles became more important, and the community structure and composition of species became more complicated with the change of communities from immature to mature stages. While the shape of the curve was suggestive, the variability limits the inference on the shape of a characteristic curve in index trajectory. What was significant was the decrease in the $J$-shaped distribution in the mature community to a low of 0.086 . That is, in the aggregate, the later successional period was associated with

\section{Discussion}

Due to similar origins as farmland and similar management history, space is used instead of a chronosequence approach (space for time substitution) for the examination of the long-term successional process, especially taking site conditions as important variables (Aravena et al. 2002; Allen and Philip 2008). In this paper, "static succession analysis" clearly describes the development and process of Larix olgensis succession on hilly lands which were previously agricultural lands. The results of the TWINSPAN classification show five different stages in the succession process: immature, juvenile, mid-aged, near-mature and mature (Fig. 2). These stages are also inferred by DCA and CCA ordination results (Figs. 2, 3, 4). The ordinations for the quadrat data reflect a high degree of similarity of the gradient relation among trends, directions and process of successional stages and site conditions, both in the other analyses and in the field (Guariguata and Ostertag 2001; post-agricultural forests involves a long-term shift between contrasting plant communities, and this successional sequence could be considered as a general model of $L$. olgensis restoration of farmlands in the Lesser Khingan Mountains.

The occurrence of plant species in number and in presence shifted over time to accommodate the development space and available soil resources (Fig. 6). As intraspecific and interspecific competition became severe with the development of species during the successional process, stand density of $L$. olgensis declined markedly, and some pioneer species as Artemisia stolonifera even disappeared. Simultaneously, the species composition at each successional stage shows the time available for their colonization which varied and became more complex within a dynamic, open forest system (Table 1). In the herb Kassi N'Dja and Guillaume 2008). The floristic recovery of 
layer, many species of shade intolerant herbs (e.g., Artemisia stolonifera) were replaced by semi-humid species (e.g., Oxalis corniculata, Sium suave). In the shrub layer, Corylus mandshurica became dominant gradually with rapid growth and regeneration. In the canopy, the dominant role of L. olgensis decreased and broad-leaved species such as Ulmus pumila and Betula platyphylla became more typical. Furthermore, the species diversities varied greatly as the succession progressed. Species heterogeneity increased gradually, but richness declined during succession. This may have resulted from $L$. olgensis excluding the diversity of bryophytes and lichens as Clark et al. (2003) reported. Although species evenness remained almost the same from the immature to mature stage, the characteristics of the community changed markedly. Overall, the results reveal that the evenly distributed pattern of $L$. olgensis on post-agricultural lands gradually changed as succession proceeded, to finally form a relatively stable plantation community. It is unknown whether this mature stage community could be a climax mixed broadleaf-conifer forest in the over-mature community (Thomas 2004).

The results of DCA and CCA ordination successfully demonstrated a process of community succession and the characteristics of plots and species distribution. When site conditions significantly improved (e.g., thicker litter layer and soil), colonization and development of some species happened spontaneously. The successional processes of plant communities are mainly influenced by time since afforestation. They are also affected by natural plant mortality and management activities such as tending, pruning and thinning. Management can be a driving force in successional development and would accelerate the growth of vegetation favorable to native adaptable species (Kalev et al. 2007). Changes in community and site conditions indicate that the transitional period from immature to mature stages is a crucial period of management. Appropriate ecosystem-based management could increase the natural evolution process (Coast Information Team 2004). In other words, unlike the slow pace of natural succession, an artificial restoration period of vegetation might be shortened through sound human management. However, this hypothesis requires further empirical study, and some underlying factors (e.g., species life history, light availability and forest microclimates) remain largely unexplored (Van and Franklin 2000; Gandolfi et al. 2007; Pieter et al. 2011).

\section{Conclusions}

As an important region of mixed broadleaf-conifer forests, the Lesser Khingan Mountains display special patterns of recovery and restoration by afforesting with Larix olgensis.
Our study shows that planting L. olgensis on post-agricultural fields has definite stages and patterns of community development and growth which are deemed beneficial for improving soil fertility and facilitating the formation of a stable community. The sequential development of this vegetation type takes approximately four decades to restore a self-maintained ecosystem. The plantations can be classified into five basic successional stages from immature to mature. The mature stage has a relatively stable community structure and improved site conditions, while L. olgensis, Corylus mandshurica and Carex lanceolata are the most common species. The establishment of the model of artificial recovery forest on hilly farmlands is of great value for matching species with site conditions, and would accelerate the community successional process through effective management.

Acknowledgements We express our sincere appreciation to Xiao-Yu Guo, Yao Fu, Yu Dong, Tian-Bo Wang, Yi-Fu Wang for their fieldwork assistance, and to the members of Langxiang Forestry Bureau for their friendship and assistance.

Open Access This article is distributed under the terms of the Creative Commons Attribution 4.0 International License (http://crea tivecommons.org/licenses/by/4.0/), which permits unrestricted use, distribution, and reproduction in any medium, provided you give appropriate credit to the original author(s) and the source, provide a link to the Creative Commons license, and indicate if changes were made.

\section{References}

Aide TM, Zimmerman JK, Rosario M, Marcano H (1996) Forest recovery in abandoned cattle pasture along an elevational gradient in Northeastern Puerto Rico. Biotropica 28(4a):537-548

Allen B, Philip L (2008) Long-term recovery of vegetation communities after harvesting in the coastal temperate rainforests of northern British Columbia. Can J For Res 38(12):3098-3111

Aravena JC, Carmona MR, Pérez CA, Armesto JJ (2002) Changes in tree species richness, stand structure and soil properties in a successional chronosequence in northern Chiloé Island, Chile. Rev Chil Hist Nat 75(2):339-360

Bradshaw AD (1997) Restoration of mined lands-using natural processes. Ecol Eng 8:255-269

Cao W, Li JY (2007) Flora and distribution in Lesser Khingan Mountains, China. Science Press, Beijing (in Chinese)

Carolina MR, Belén FS (2005) Natural revegetation on topsoiled mining-spoils according to the exposure. Acta Oecol 28:231-238

Chitra BB, Torstein S, Ole RV (2009) Temporal changes in species diversity and composition in abandoned fields in a transHimalayan landscape, Nepal. Plant Ecol 201(2):383-399

Clark DF, Antos JA, Bradfield GE (2003) Succession in sub-boreal forests of west-central British Columbia. J Veg Sci 14(5):721-732

Clifford HT, Stephenson W (1975) An introduction to numerical classification. Academic Press, London

Coast Information Team (2004) Ecosystem-based management planning handbook. Retrieved 18 June 2011, from http://www. citbc.org/pubpcit.html 
Connell JH, Slatyer RO (1977) Mechanisms of succession in natural communities and their role in community stability and organization. Am Nat 111:1119-1144

Elgersma AM (1998) Primary forest succession on poor sandy soils as related to site factors. Biodivers Conserv 7:193-206

Gandolfi S, Joly CA, Rodrigues RR (2007) Permeability-impermeability: canopy trees as biodiversity filters. Sci Agric 64:433-438

Guariguata MR, Ostertag R (2001) Neotropical secondary forest succession: changes in structural and functional characteristics. For Ecol Manag 148:185-206

Hill MP (2005) WinTWINs. TWINSPAN for Windows Version 23. Retrieved 6 Aug 2011, from www.ceh.ac.uk/products/software/ wintwins.html

Howorth RT, Pendry CA (2006) Post-cultivation secondary succession in a Venezuelan lower montane rain forest. Biodivers Conserv 15:693-715

Jacquemyn H, Rein B (2008) Effects of stand age on the demography of a temperate forest herb in post-agricultural forests. Ecology 89:3480-3489

Jerônimo BBS, Pablo VP, Luiz FDM, Pablo JFPR (2011) Natural regeneration in plantations of native trees in lowland Brazilian Atlantic Forest: community structure, diversity, and dispersal syndromes. Restor Ecol 19(3):379-389

Joana S, Miguel P, Luís R, Pedro B (2011) Long-term understory recovery after mechanical fuel reduction in Mediterranean cork oak forests. For Ecol Manag 261(3):447-459

Jordan WR, Gilpin ME, Aber JD (1987) Restoration ecology: a synthetic approach to ecological research. Cambridge University Press, Cambridge

Kalev J, Timo K, Ahto K (2007) Disturbances at multiple scales as the basis of forest ecosystem restoration and management. For Ecol Manag 250:1-2

Karel P, Petr P (2001) Using spontaneous succession for restoration of human-disturbed habitats: experience from Central Europe. Ecol Eng 17:55-62

Kassi N'Dja JK, Guillaume D (2008) Successional patterns of plant species and community diversity in a semi-deciduous tropical forest under shifting cultivation. J Veg Sci 19:809-820

Kathryn MF, Mark V (2005) Recovery of forest plant communities in post-agricultural landscapes. Front Ecol Environ 3:243-250

Leendertse PC (1997) Long-term changes (1953-1990) in the salt marsh vegetation at the Boschplaat on Terschelling in relation to sedimentation and flooding. Plant Ecol 132:49-58

Lep J, Milauer P (2003) Multivariate analysis of ecological data using CANOCO. Cambridge University, Cambridge

Li DK, Zhuo J, Sun ZH (2008) Monitoring the effects of ecosystem restructuring project after returning farmland to forest based on RS and GIS. Trans Chin Soc Agric Eng 24(12):120-126

Liu XZ, Zhang F, Shao HB, Zhang JT (2011) Community succession analysis and environmental biological processes of naturally colonized vegetation on abandoned hilly lands and implications for vegetation restoration strategy in Shanxi, China. Afr J Biotechnol 10(7):1133-1145

Lu DL, Mausel P, Brondizio E, Moran E (2003) Classification of successional forest stages in the Brazilian Amazon Basin. For Ecol Manag 181:301-312

Luisa M, Gabriela V, Salvador S (2001) Spatial and temporal variability during primary succession on tropical sand dunes. J Veg Sci 12:361-372

Man XL, Liu B, Li Y (2010) Distribution characteristics of organic carbon, nitrogen and phosphorus in the soils of herbaceous peat swamps in the Xiaoxing'an mountains. J Beijing For Univ 32(6):48-53
McKeague JA (1978) Manual on soil sampling and methods of analysis. Canadian Society of Soil Science, Ottawa, p 212

Nichols OG, Nichols FM (2003) Long-term trends in faunal recolonization after bauxite mining in the Jarrah forest of southwestern Australia. Restor Ecol 11:261-272

Peter DH, Harrington C (2009) Six years of plant community development after clearcut harvesting in western Washington. Can J For Res 39(2):308-331

Pielou EC (1975) Ecological diversity. Wiley, New York

Pieter DF, Lander B, Bente J, Graae JB, Monika W, Anna O, Annette K, Ivy J, Aurélien J, Hans J, Martin H, Martin D, An DS, Michele DS, Guillaume D, Sara AO, Cousins KV (2011) Interregional variation in the floristic recovery of post-agricultural forests. J Ecol 99(2):600-609

Pinder JE, Kroh GC, White JD, Basham MAM (1997) The relationships between vegetation types and topography in Lassen Vocalnic National Park. Plant Ecol 131:17-29

Rivera LW, Zimmerman JK, Aide TM (2000) Forest recovery in abandoned agricultural lands in a karst region of the Dominican Republic. Plant Ecol 148:115-125

Ruiz-Jaen MC, Aide MT (2005) Vegetation structure, species diversity, and ecosystem processes as measures of restoration successes. For Ecol Manag 218:159-173

Sarmiento L, Llambi LD, Escalona A, Marquez N (2003) Vegetation patterns, regeneration rates and divergence in an old-field succession of the high tropical Andes. Plant Ecol 166:145-156

Souza FM, Batista JLF (2004) Restoration of seasonal semideciduous forest in Brazil: influence of age and restoration design on forest structure. For Ecol Manag 191:185-200

Stephane MM, Dawn RB (2001) Recovery patterns of understory herbs and their use as indicators of deciduous forest regeneration. Conserv Biol 15(1):98-110

Ter Braak CJF, Šmilauer P (2002) CANOCO Reference Manual and CanoDraw for Windows User's Guide: Software for Canonical Community Ordination (version 4.5). Microcomputer Power, Ithaca, NY

Thomas JME (2004) Positive impact forestry: a sustainable approach to managing woodlands. Island Press, Washington

Toledo M, Salick J (2006) Secondary succession and indigeneous management in semideciduous forest fallows of the Amazon Basin. Biotropica 38:161-170

Van PR, Franklin JF (2000) Influence of canopy structure on the understory environment in tall, old-growth, conifer forests. Can J For Res 30(8):1231-1245

Wang J, Borsboom AC, Smith GC (2004) Flora diversity of farm forestry plantations in southeast Queensland. Ecol Manag Restor $5: 43-51$

Wang CM, Shao B, Wang RN (2010) Carbon sequestration potential of ecosystem of two main tree species in Northeast China. Acta Ecol Sin 30(7):1764-1772 (in Chinese with English abstract)

Whittaker RH (1972) Evolution and measurement of species diversity. Taxon 21:213-251

Zhang XJ, Wang QC, Wang SL, Sun Q (2011) Effect of the close-tonature transformation of Larix gmelinii pure stands on plant diversity of understory vegetation in Xiaoxing'an Mountains of China. Sci Silvae Sin 47(1):6-14 (in Chinese with English abstract)

Publisher's Note Springer Nature remains neutral with regard to jurisdictional claims in published maps and institutional affiliations. 